\title{
Bequests to Educational Institutions: Who Gives and Why?
}

Received (in revised form): 19th July, 2007

\section{Claire Routley}

is a Ph.D. student at Bristol Business School, researching legacy giving motivations. She is Legacy and In Memoriam Marketing Manager for UK-based charity, Help the Aged.

\section{Adrian Sargeant}

is the Robert F. Hartsook Professor of Fundraising at Indiana University. He was previously the chair of the Centre for Voluntary Sector Management at Henley Management College in the U.K, and a professor of nonprofit marketing at Bristol Business School. Professor Sargeant is the author of Fundraising Management and Marketing Management for Nonprofit Organizations published by Routledge and the Oxford University Press, respectively.

\section{Wendy Scaife}

is a senior research fellow in the Centre of Philanthropy and Nonprofit Studies at the Queensland University of Technology in Australia, and researches and teaches in nonprofit management and marketing, fundraising, and corporate community involvement. Wendy was part of the team on the Giving Australia research study and has completed best practice fundraising studies in arts, sport, and medical research. Current research projects include work in local government and philanthropy as well as reviewing fundraising training in Australia.

\section{Abstract}

Bequests have played an important role in the foundation and development of many educational organizations. It is possible that as mortality rates increase, bequest income will become even more vital. In order to maximize income from this source, practitioners need to understand both who leaves bequests, and what their motivations may be for doing so. This study analyzes literature from the fields of marketing, sociology,

Author's Contact Address:

Claire Routley

Help The Aged

207-221 Pentonville Rd

London, NI $9 \mathrm{UZ}$

Tel: 02072397558

E-mail: routley@helptheaged.org.uk economics, and sociology to provide an insight into both who gives and why. The findings show that individuals from across the donor base may be receptive to a bequest appeal, and that there appear to be both altruistic and egoistic motivations driving the bequest giving decision. The study concludes with suggestions as to how these findings may be incorporated into practitioners' bequest fundraising.

International Journal of Educational Advancement (2007) 7, 193-201. doi:10.1057/palgrave.ijea.2150061

Keywords:

bequests, bequest motivations, planned giving 


\section{Introduction}

Bequest income has been vital to educational institutions for centuries, from William of Durham's bequest in 1249, which eventually founded University College, Oxford, to John Harvard's gift of $£ 779$ in 1638 to the Institution that now bears his name. Bequests are also highly significant for the wider nonprofit sector. In the United States, giving by bequest in 2006 has been estimated at $\$ 22.91$ billion (Giving USA, 2007), and in the $\mathrm{UK}$, the market was worth over $£ 1.6$ billion in 2004-2005 (Reichardt et al., 2007). Impressive though these figures are, there remains considerable scope to increase the value of bequests to the sector, particularly as mortality rates increase (with the passing of the baby boom generation) and a greater percentage of society are persuaded to give in this way. In the UK, for example, the percentage of wills containing a charitable bequest has increased in recent years to around 8 percent of the total, but given that over 80 percent of the population will give in their lifetime, the potential for expansion is clear (Sargeant and Radcliffe, 2007).

In the US, Schervish and Havens (1999) have estimated that the years between 1998 and 2052 will see at least \$41 trillion dollars transferred between generations through inheritance, but that the final total could be double or even triple this figure. Schervish also offers a conservative estimate of the amount that will be transferred to nonprofits, namely $\$ 6$ trillion. His more optimistic models indicate that this could be as high as \$25 trillion. While some commentators have questioned the validity of these original estimates (see Havens and Schervish, 2003), there is no doubt that the next 50 years will witness an unprecedented wealth transfer, and consequently an enormous opportunity for the generation of bequests.

Despite its importance, the topic of charitable bequests remains grievously under-researched, with the majority of empirical studies focusing on the factors that drive lifetime giving. In this paper, we summarize the extant bequest research, but also review the wider marketing, sociology, economics, and psychiatry literature for material offering utility for practitioners involved in this form of fundraising. Our review was completed in June 2007 using the Business Source Premier, PsycBITE. PsycINFO, SocINDEX, and UMI dissertation databases.

We begin by considering which individuals are most likely to leave a bequest to nonprofit organizations, before considering what motivations are likely to drive their giving decisions. We conclude with suggestions to practitioners as to how these insights may benefit bequest fundraising within educational institutions.

\section{Bequest Givers}

The first challenge faced by fundraisers is undoubtedly whom they should approach for a bequest gift. In the US, where bequests have typically been integrated into the marketing of planned giving, targeting has often been very specific and often a component of major gift fundraising targeted at the wealthy. In the UK, by contrast, bequest solicitations are routinely made across the supporter base although 
where nonprofits can identify the age of their supporters (perhaps by their method of giving), particular attention is paid to the elderly (Sargeant and Jay, 2004). Women have also been a particular target for attention, since they live longer than do men and are therefore more likely to have responsibility for disposing of the balance of an estate. Numerous studies, including Sargeant and Jay (2003), Sargeant and Hilton (2005), and Sargeant et al. (2006b), now confirm that the majority of individuals pledging to leave a bequest are female.

In a bid to improve the targeting of appeals beyond this generic, Sargeant and Hilton (2005) and Sargeant et al. (2006b) have profiled bequest pledgers in both the UK and the US. Their results, when considered alongside critical studies such as that conducted by the National Committee on Planned Giving (NCPG, 2001), indicate that in the UK pledgers are typically in their mid to late 60s and approximately ten years older than the balance of the supporter base. In the US, the age profile is less distinct with donors pledging gifts from their mid-40s and pledgers being generally indistinguishable on the basis of age from the balance of the database (Brown, 2004; Sargeant et al., 2006a,b). Sargeant (2005) has argued that these differences between the two countries are a function of historic variations in bequest fundraising practice and suggests that bequest solicitations should ideally be ubiquitous and offered to all categories of supporters irrespective of their age. The basis for this assertion is simply that many wills are made early and NCPG (2001) data identified that once donors do take the step of including a charitable bequest in their will, they are unlikely to remove it. NCPG found that 75 percent of charitable bequests are never revised. If they are, the size of the donation is typically increased, rather than being decreased or removed altogether.

Income and wealth may also be used as the basis for segmenting potential bequest givers. Unsurprisingly, wealthier donors leave bequests of the greatest financial value and wealthier donors are also significantly more likely to leave a bequest (Barthold and Plotnick, 1984; Chang et al., 1999; Joulfaian, 2000). Interestingly, wealth also drives the percentage of an estate that will be allocated to good causes. As the value of final estates increases, so too does the percentage left to nonprofits. In 2003, charities received 5 percent of the smallest estates, 17 percent of estates worth $\$ 10$ million-\$20 million, and 32 percent of estates worth over $\$ 20$ million. Indeed, 43 percent of the total bequeathed to charity by US estate tax filers in 2003 came from the largest estates, even though those estates numbered just 721 out of 66,000 (Schervish et al., 2006).

However, while the probability of leaving a charitable bequest may increase in line with socioeconomic status, Brown (2004) tells us that 58 percent of US bequests are actually left by donors with incomes of less than $\$ 75,000$ a year. Similarly, in the UK, Sargeant and Hilton (2005) and Sargeant and Jay (2003) find that pledgers' household income is significantly smaller than that of the general supporter base. It would appear that, in both countries, many potential bequest donors are "cashpoor-asset-rich" and could therefore 
appear as lower value donors on a charitable database.

Married individuals and those with children and grandchildren are less likely to make a charitable bequest (see Barthold and Plotnick, 1984; Chang et al., 1999; Joulfaian, 2000; Sargeant and Jay, 2003; Sargeant and Jay, 2004; Sargeant and Hilton, 2005; Sargeant et al., 2006a, b). Rawlingson and McKay (2005) point out that 25 percent of UK wills are total estate wills, bequeathing everything to a surviving spouse, and that while only a small percentage of wills include a donation, these wills are made disproportionately by those without immediate family heirs-only 1 percent of grandparents include a nonprofit in their wills in comparison to 16 percent of childless people aged over 45 .

Finally, other profiling work on bequest donors suggests that bequests are more likely to be offered by individuals of faith (Barthold and Plotnick, 1984; McGranahan, 2000) and individuals who plan well ahead for the disposition of their estate (McGranahan, 2000). Bequest donors are also likely to have resided at one address for up to ten years. Interestingly, Chang et al. (1999) find that a tenure of over ten years reduces an individual's propensity to bequeath.

\section{Motives for Leaving a Charitable Bequest}

It could be argued that a bequest is the most altruistic of gifts; writing a charity into their will means that a donor will not be alive to receive any approbation for the gift they have given. Of course, some donors are able to benefit from their gift by informing their chosen charity that they intend to leave a gift; however, a surprising number of donors do not inform an organization of their forthcoming bequest. Research from Sargeant and Jay (2003, 2004) shows that only 42.7 percent of UK supporters and 67 percent of US supporters would notify an organization of their intentions. Similarly, in a study of 15 years of records at a large US nonprofit, DameGreen (2003) found that fewer than one donor in 14 notified the charity that they had named them as a beneficiary in their will.

In the only empirical study of bequest pledger motives, Sargeant et al. (2006b) identify a range of "general" charitable motives for leaving a bequest. They find evidence that both altruism and affinity with the cause/empathy have a role to play in this context. They also identified that pledgers were significantly more concerned that the organization be performing well and delivering them (as donors) a high quality of service. The authors stress this latter aspect of their study, as bequest pledgers were found to be significantly more demanding of the organization they were supporting in almost every respect. Pledgers demand a differentiated standard of care and pay particular attention to the communications they receive. In addition, Sargeant et al. $(2006 \mathrm{a}, \mathrm{b})$ highlight a number of "specific" motives for leaving a charitable bequest, such as a lack of family need, the avoidance or reduction of tax, a need to live on, and "spite" (i.e. some individuals felt aggrieved at the way they had been treated by relatives and sought to ensure that their wealth would not be left to them after their passing). 
Of particular interest to educational institutions may be the motive of reciprocity, or the need to give something back, which has also been highlighted by Sargeant and Hilton (2005). The authors demonstrate that reciprocity is a stronger motive in the context of bequests than it is in lifetime giving. Many donors appear to want to "pay back" an organization for services that have been provided to themselves or a loved one and a bequest offers a particularly suitable vehicle for those who may lack the cash to do so in their lifetime. The reciprocity motive has particular resonance in the context of educational giving where many alumni may be moved to give in this way, perhaps out of a sense of gratitude for their success and a desire to give others the same opportunity (Schervish, 2000a, b).

Sargeant et al. (2006b) found that the need to "live on" was a highly significant motive for bequest giving while Curasi et al. (2003, p. 372) describe the desire for immortality as one of "the strongest and least malleable of human motives shaping the later adult years." In a similar vein, it has been noted that the last will and testament plays a vital role in fixing the deceased's identity within the minds of survivors (Unruh, 1983). It is possible that individuals seek to manage how they will be remembered through leaving a bequest to mark their affiliation with a particular cause or organization. It is possible, for example, that a bequest to a church will situate someone as a committed Christian, while a bequest to an educational institution may memorialize the donor as a member of the intelligentsia or as a college graduate.
There is also evidence that being remembered by posterity may be especially important to wealthy or super-wealthy individuals. In her study of wealthy consumers, Hirschman (1990) discusses the concept of "secular immortality," which, she argues, is obtained when "superlative or supranormal achievements in some realm of social endeavour culminate in legendary status" (Hirschman, 1990, p. 31). In order to achieve secular immortality, a bequest can be deliberately designed to manage how an individual is remembered by succeeding generations and society at large. This may be of particular relevance to educational institutions, who can memorialize their donors with naming opportunities on buildings, academic posts, or notable research projects.

The sociology literature suggests that the related concept of generativity may have much to offer bequest fundraisers. Kotre (1996) defines it as "a desire to invest one's substance in forms of life and work that will outlive the self" and makes the distinction between biological generativity (conceiving and bearing children) and cultural generativity (the passing on of values). As Rubinstein's (1996) study of childless women found, the latter can be a particularly powerful motive. The author found that the feeling that there was no-one to leave a bequest to, or no point in doing so, led to feelings of sadness or despair. It therefore appears that the desire to leave a bequest is deeply ingrained in the human psyche.

Interestingly, it appears as though middle age is a particularly critical time. Both McAdams et al. (1997) and Kotre (1996) describe this period as 
"highly generative." As individuals move into this stage of their lifecycle, it becomes increasingly important for them to develop an anticipated ending for their life story, which "ties together the beginning and middle to affirm unity, purpose and direction in life over time" (McAdams, 1996, p. 309). As individuals move through middle age and beyond, "they begin to define themselves in terms of those things, people and ideas they leave behind" (McAdams, 1996, p. 312). While generativity expresses a concern for forthcoming generations, at the same time it is also "me-centered," focusing on how the individual can extend their sense of self forwards in time. While the link between generativity and leaving a charitable bequest has yet to be researched in great depth, it is possible that generativity may be a key motive for bequest giving. It could also be particularly important in the decision to leave a charitable bequest to an educational institution since when offering a gift of this nature, not only is a donor achieving a form of symbolic bequest, but they are directly providing for forthcoming generations, a key feature of generativity.

A further key motive would be a positive outcome from what psychologists refer to as the process of reminiscence. Old age, with its increasing awareness of approaching death, has been posited as a time when people become increasingly self-aware (Butler, 1963). This increased selfawareness could be driven, at least in part, by the life-review, a process described by theorists such as Butler (1963, p. 66) as "a naturally occurring, universal mental process characterized by the progressive return to consciousness of past experiences.”
According to Butler (1963, p. 69), the life-review can result in a substantial re-organization of the personality. It is possible that the process of making a will could act as a trigger for the lifereview process; indeed, it is likely that considering the distribution of assets and treasured possessions would trigger reminiscence about the people, places, and processes involved in their accumulation, including time spent at various educational institutions. It is possible that the people, places, and organizations that feature positively in this process of reminiscence could become beneficiaries of an individual's estate. In effect, gratitude for a positive experience becomes a motive for a bequest, whether or not an individual feels the need to formally "reciprocate" referred to earlier.

Finally, no discussion of bequest motives would be complete without a consideration of estate tax. While many organizations promote bequest giving as a tax reduction strategy, the academic evidence for this motivation is mixed and many writers and professionals now see the issue of tax as a rationale for opening a dialogue with a donor, rather than a motive for giving per se (Sargeant and Radcliffe, 2007). Researchers such as Barthold and Plotnick (1984), Clotfelter (1985), and Auten and Joulfaian (1996) have identified some incentive effects of inheritance tax on charitable giving, but in the United States, it still appears that nearly two-thirds of the elderly for whom estate tax may loom as a potential burden are not making transfers that would substantially reduce their estate taxes and hence the net-of-tax bequest received by their heirs (Poterba, 2001). This is highly significant since it suggests that while 
bequests may appear altruistic in nature, individuals may derive more utility from the amount they are able to leave than from the amount their heirs can consume (Blinder, 1974; Hurd, 1989). Economists refer to this as the bequest motive, and recent work by Kopczuk and Lupton (2005) indicates that individuals motivated in this way will spend on average 25 percent less on personal outlays than the balance of the population. This work is highly relevant to fundraisers since it suggests that individuals with a bequest motive may well appear as lower value donors on a database. The egoistic driver of the bequest motive is also something that could form a component of a solicitation campaign.

\section{Conclusions and Advice for Practitioners}

Bequest fundraising offers huge opportunities for educational institutions, who, like other nonprofit organizations, could benefit significantly from the forthcoming wealth transfer. In order to take full advantage of these opportunities, however, educational institutions must be aware of the complex and multifaceted motivations of potential bequest donors and be able to adapt their bequest marketing strategies accordingly.

It would appear that a range of individuals from across the donor base may be receptive to the bequest giving message, and that bequest giving messages should not be restricted to donors with a particular demographic or giving profile. There may be particular opportunities in bequest appeals to alumni and their loved ones, who may wish to reciprocate for their educational opportunities. The finding that those with a bequest motive spend $18-25$ percent less than those without such a motive implies that many potential bequest givers will be at the lower end of a fundraising database by value. When one considers that many potential legators are likely to asset rich-cash poor, the utility of maintaining some form of dialogue with low or even negative value supporters, is clear.

In addition to appealing to a donor's altruistic motivations, fundraisers should be aware that egoistic motivations also appear to be important in the bequest giving decision. Individuals should be encouraged to give because of the real and tangible difference that they themselves could make. Encouraging giving to general funds is unlikely to be an optimal strategy. The literature suggests that organizations would fare better asking for funding for a specific purpose, or offering alternatives that the donor could select between for themselves. It will also be important to provide excellent standards of donor care and communication to bequest pledgers in order to reinforce their importance to the organization and the difference they can make.

Similarly, being remembered positively by loved ones and, indeed, by posterity for leaving a bequest appears to be important for some groups of donors. The positioning of the bequest gift is therefore key as is the aftercare that could be provided to a legator's descendants. Indeed, there may be considerable scope here for a charity to add genuine value to the pledger relationship through a range of remembrance vehicles. It may also be possible for charities to integrate this 
knowledge into promotional material and to trigger this positive process of remembrance through family discussion and the sharing of experiences and priorities.

The literature has highlighted the role of story telling and reminiscence as part of the process of life review. Since this process is a natural part of aging, charities may wish to investigate ways in which they could utilize story telling and reminiscence. At a very simple level, this may mean engaging in a dialogue with donors and encouraging them to pass on their stories to the organization. It might also mean the facilitation of storytelling to a pledger's family or friends. In this way, the bequest gift could become an expression of self and bolster feelings of self-esteem, worth, and achievement.

\section{References}

Auten, G. and Joulfaian, D. (1996), "Charitable contributions and intergenerational transfers," Journal of Public Economics, 59, 1, pp. 55-68.

Barthold, T. and Plotnick, R. (1984), "Estate taxation and other determinants of charitable bequests," National Tax Journal, 37, 2, pp. 225-237.

Blinder, A.B. (1974), Toward an Economic Theory of Income Distribution, MIT Press, Cambridge, MA.

Brown, D.W. (2004), "What research tells us about planned giving," International Journal of Nonprofit \& Voluntary Sector Marketing, 9, 1, pp. 86-95.

Butler, N. (1963), “The life review: An interpretation of reminiscence in the aged," Psychiatry, 26, pp. 65-76.

Chang, C.F., Okunade, A.A. and Kumar, N. (1999), "Motives behind charitable bequests," Journal of Nonprofit and Public Sector Marketing, 6, 4, pp. 69-85.

Clotfelter, C.T. (1985), "Charitable giving and tax legislation in the Reagan era," Law and Contemporary Problems, 48, pp. 197-212.

Curasi, C.F., Price, L.L. and Arnould, E.J. (2003), "Understanding the intergenerational transmission of cherished possessions: Insights for estate planning, trust officers and other end-of-life professionals," Journal of Financial Services Marketing, 7, 4, pp. 369-383.

DameGreen, S. (2003), "How to develop a successful bequest program: A simple easyto-follow plan for starting, increasing and collecting bequests at your nonprofit," Journal of Gift Planning, 7, 2, pp. 7-52.

Giving USA (2007), The Annual Report on Philanthropy for the year 2006. Giving USA Foundation.

Havens, J.J. and Schervish, P.G. (2003), "Why the $\$ 41$ trillion wealth transfer estimate is still valid: A review of challenges and questions," Journal of Gift Planning, 7, 1, pp. 11-15, 47-50.

Hirschman, E.C. (1990), "Secular immortality and the American ideology of affluence," Journal of Consumer Research, 17, 1, pp. 31-43.

Hurd, M.D. (1989), "Mortality risk and bequests," Econometrica, 57, 4, pp. 79-813.

Joulfaian, D. (2000), "Estate taxes and charitable bequests by the wealthy," National Tax Journal, 53, 3, pp. 743-763.

Kopczuk, W. and Lupton, J.P. (2005), “To leave or not to leave the distribution of bequest motives [Homepage of National Bureau of Economic Research] [Online]. Available: http://papers.nber. org/papers/11767.

Kotre, J. (1996), Outliving the Self, 2nd edn, W W Norton and Company, New York and London.

McAdams, D.P. (1996), "Personality, modernity, and the storied self: A contemporary framework for studying persons," Psychological Inquiry, 7, 4, pp. 295-321.

McAdams, D.P., Diamond, A., De St. Aubin, E. and Mansfield, E. (1997), "Stories of commitment: The psychosocial construction of generative lives," Journal of Personality and Social Psychology, 72, 3, pp. 678-694.

McGranahan, L.M. (2006), "Charity and the bequest motive: Evidence from seventeenth century wills," Journal of political Economy, 108, 6, pp. 1270-1291.

NCPG (2001), Planned Giving in the United States, National Committee on Planned Giving, Indianapolis, IN.

Poterba, J. (2001), "Estate and gift taxes and incentives for incentives for inter vivos giving in the US," Journal of Public Economics, 79, pp. 237-264.

Rawlingson, K. and McKay, S. (2005), Attitudes to Inheritance in Britain, Joseph Rowntree Foundation, The Policy Press, Bristol.

Reichardt, O., Wilding, K. and Kane, D. (2007), The Voluntary Sector Almanac: the State of the Sector, NCVO, London.

Rubinstein, R.L. (1996), "Childlessness, bequest, and generativity," Generations, 20, 3, pp. 58-60. 
Sargeant, A. (2005), "Understanding bequest giving," AFP Conference-Greater Toronto Chapter. Toronto Convention Centre, Toronto, November.

Sargeant, A. and Hilton, T. (2005), "The final gift: Targeting the potential charity legator," International Journal of Nonprofit and Voluntary Sector Marketing, 10, pp. 3-16.

Sargeant, A., Hilton, T. and Wymer, W. (2006a), "Bequest motive and barriers to giving: The case of direct mail donors," Nonprofit Management and Leadership, 17, 1, pp. 49-66.

Sargeant, A. and Jay, E. (2003), "The efficacy of bequest communications [online]. Available at: http://www.charityfundraising.org/US percent20bequest percent20fundraising.pdf.

Sargeant, A. and Jay, E. (2004), "Determinants of US donor behaviour: The case of bequests [online]. Available at: http:// www.charityfundraising.org/Bequest percent20fundraising percent20in percent 20 the percent20UK.pdf.

Sargeant, A. and Radcliffe, R. (2007), "How come people leave legacies at all?" Institute of Fundraising National Convention, July, London.
Sargeant, A., Wymer, W. and Hilton, T. (2006b), "Marketing bequest club membership: An exploratory study of bequest pledgers," Nonprofit and Voluntary Sector Quarterly, 35, 3, pp. 84-404.

Schervish, P.G. (2000a), "The material horizons of philanthropy: New directions for money and motives," New Directions for Philanthropic Fundraising, 29, pp. 5-16.

Schervish, P.G. (2000b), "The spiritual horizons of philanthropy: New directions for money and motives," New Directions for Philanthropic Fundraising, 29, pp. 17-31.

Schervish, P.G. and Havens, J. (1999), "Millionaires and the millennium: New estimates of the forthcoming wealth transfer and the prospects for a golden age of philanthropy. Social Welfare Research Institute, Boston College, Boston, MA [online]. Available at http://www.bc.edu/bc_org/ avp/gsas/swri/swri_features_wealth_trasnfer_ report.htm.

Schervish, P.G., Havens, J. and Whitaker, A.K. (2006), "Leaving a bequest of care," Philanthropy, 20, 1, pp. 11-13.

Unruh, D.R. (1983), "Death and personal history: Strategies of identity preservation," Social Problems, 30, 3, pp. 340-351. 